\title{
ロジスティック回帰分析を用いた既存地すべり地形の地震時の危険度評価 An approach of susceptibility analysis for deep-seated landslide induced by earthquake within pre-existing landslide topography using logistic regression
}

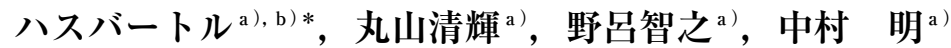 \\ Bateer HASI, Kiyoteru MARUYAMA, Tomoyuki NORO and Akira NAKAMURA
}

\begin{abstract}
This paper conducted logistic regression analysis for landslides induced by earthquake within pre-existing landslide topographies. The logistic regression model constructed by using the landslides data set from the Chuetsu earthquake. The results showed that surface roughness and marginal erosion ratio are the most influential factors for the landslide occurrence. The model was validated by the landslides data set of the Chuetsu earthquake and the Iwate-Miyagi inland earthquake. Based on ROC curves, the AUC is larger than 0.8 , showed good prediction accuracy and suggested the method is useful. Key words : landslide, earthquake, pre-existing landslide topography, logistic regression

\section{和文要旨}

地震による地すべりの発生危険度を評価するため，既存地すべり地形を対象にロジスティック回帰分析を行った。この分析では， 中越地震で地すべりが多発した範囲の既存地すべり地形と地震による地すべりデータを用いて，ロジスティック回帰モデルを構築 し，標高偏差と地すべり地形の縁辺侵食率が，地震による地すべりの発生に最も影響していることを明らかにした。また，構築し たモデルを用いて，中越地震による地すべりの一部と岩手・宮城内陸地震による地すべりの各発生を予測した結果，その精度はROC 解析によればAUC (予測能) が0.8以上で，モデルの有効性が確認された。

キーワード：地すべり，地震，既存地すべり地形，ロジスティック回帰分析
\end{abstract}

\section{1. はじめに}

地震による災害では，地すべりや崩壊などの斜面災害 の占める割合が大きい。特に，日本のような国土の大部 分が山地からなる地域では, 地震による地すべりがライ フラインの破壊や河道閉塞などを発生させ，その被害は 深刻である。近年，日本では2004年新潟県中越地震（国 土交通省砂防部，2005) や2008年岩手・宮城内陸地震 (国 土交通省砂防部，2008)，日本以外のアジア地域でも， 例えばパキスタン北部地震（丸井ほか，2006），中国四 川地震（Chigira et al., 2010）などに伴い数多くの地す ベりが発生し，甚大な被害をもたらした。地震に伴う被 害を軽減するためには，地すべり発生の危険度を評価す ることが一つの重要な取り組みとなる。

地すべりの発生危険度評価に関する研究は数多くあり, その研究手法は主に定性的な手法と定量的な手法に分け られる（Soeters and van Westen, 1996）。定性的な手法 (Anbalagan, 1992 ; Yoshimatsu and Abe, 2006 ; 八木 ほか,2009）は専門家の経験に基づき地すべりの危険度 マップを作成する方法であり，研究者のスキルに頼るた め専門的な知識が要求される。一方，定量的な手法には 確定手法（Pack et al.，1998；Zhou et al，2003） と統 計学的な手法がある。確定手法は物理的なメカニズムを 数学モデル化するものであり, 斜面構成物の物性值が必 要になるが，その取得は困難な場合が多い。これに対し，

* 連絡著者/corresponding author

a）(独)土木研究所 雪崩・地すべり研究センター

Public Works Research Institute, Japan

b) アジア航測株式会社 社会基盤システム開発センター

Asia Air Survey, Co., Ltd.

干215-0004 神奈川県川崎市麻生区万福寺1-2-2

1-2-2, Manpukuji, Asao district, Kawasaki, Kanagawa Prefecture
統計学的な手法は，地すべりの空間分布と発生要因との 関係を分析するものである。統計学的な手法として, 判 別分析 (Lee et al. , 2008 ; Dong et al., 2009) とロジ スティック回帰分析 (Guzzetti et al., 1999 ; Ayalew and Yamagishi, 2005 ; Chang et al., 2007 ; GarciaRodriguez et al., 2008）が用いられている。判別分析 ではデータの正規分布が要求される (Dong et al., 2009) 制限があるのに対し，ロジスティック回帰分析にはこの ような制限はなく，地すべり発生予測に適しているとさ れる (Chauhan, et al., 2010)。

これらの統計学的な手法は，斜面をグリッドに分け， グリッド単位で分析を行っている場合が多い。しかし， 地すべり対策に着目した場合，危険度評価されたグリッ ドを，現実的にどのように対応するかが課題となる。地 すべり対策は一般に地すべり地形（ブロック単位）を対 象としている。地震による地すべりにおいても，既存地 すべり地形内で数多くの地すべりが発生していることが 報告されている（例えばハスバートルほか，2009）。こ のため, 既存地すべり地形の把握から, 地震による地す ベりの危険度評価が重要である。また，地形特徵に基づ く既存地すべり地形の判読など定性的な評価は比較的容 易であり,その判読結果は日本では容易に入手できる(防 災科学技術研究所，2010）。これらのことを踏まえ，本 研究では今後の地すべり斜面の対策を考慮し, 既存地す ベり地形を対象に，定性的な手法（地すべり地形判読） と客観性の高い統計手法（ロジスティック回帰分析）を 組み合わせ，地震による地すべりの発生危険度評価手法 について検討した。 
本研究では，まず中越地震で発生した地すべりと既存 地すべり地形のデータセットを作成し，その一部を用い てロジスティック回帰モデルを構築した。次に，構築し たモデルを，モデル構築に使わなかった中越地震の残り のデータと岩手・宮城内陸地震による地すべりデータに 適用し，モデルの有効性についての交差検定を行った。 その後，このモデルを用いて，上述の二つの地震による 地すべりの危険度評価図を作成した。

\section{2. 調査範囲とその概要}

調査地は中越地震と岩手・宮城内陸地震の震源域であ る。図- 1 に調査位置を示した。調査地 1 は, 中越地震 によって地すべりが数多く発生した芋川流域及びその周 辺約 $127 \mathrm{~km}^{2}$ の範囲である。調査地 2 は, 岩手・宮城内 陸地震で地すべりが多発した約 $459 \mathrm{~km}^{2}$ の範囲である。

調査地 1 の中越地震（M6.8）は，2004年10月23日に 新潟県中部に位置する東山丘陵の南部で発生した。中越 地震による直接的な犠牲者は 16 名であり，その内 6 名が 地すべりによって被災している（新潟県，2009）。調査
地 1 は，東山丘陵の中部から南部に位置し，稜線の標高 が300〜 700mの丘陵地帯である。地質は主に新第三紀か ら第四紀の地層からなり，砂岩，泥岩，砂岩・泥岩互層， シルト岩及び未固結の礫, 砂, 泥が分布する。地質構造 は北北東－南南西方向の軸を持つ活褶曲によって特徴付 けられ，それらは約 $1 \mathrm{~km}$ の間隔で分布する（柳沢ほか, 1986 ; 小林ほか, 1991)。

調査地 2 の岩手・宮城内陸地震（M7.2）は，2008年 6 月14日に奥羽脊梁山地の中部で発生した。この地震に よって17名が死亡し，6名が行方不明になっている。死 亡・行方不明者のほとんどは地すべりなどの土砂災害に よるとされている（牛山・太田，2009）。調査地 2 は奥 羽脊梁山地の東麓に位置し，稜線の標高が $400 〜 600 \mathrm{~m} て ゙$, 幾つかの河川によって深く下刻されている。地質は主に 中新世中期から鮮新世の火山岩類, 浅海性凝灰質堆積物 からなる（大沢・滝沢，1992）。また，調査地の西側に 第四紀火山である栗駒山があり，その周辺には第四紀の 火山噴出物が広く分布する。

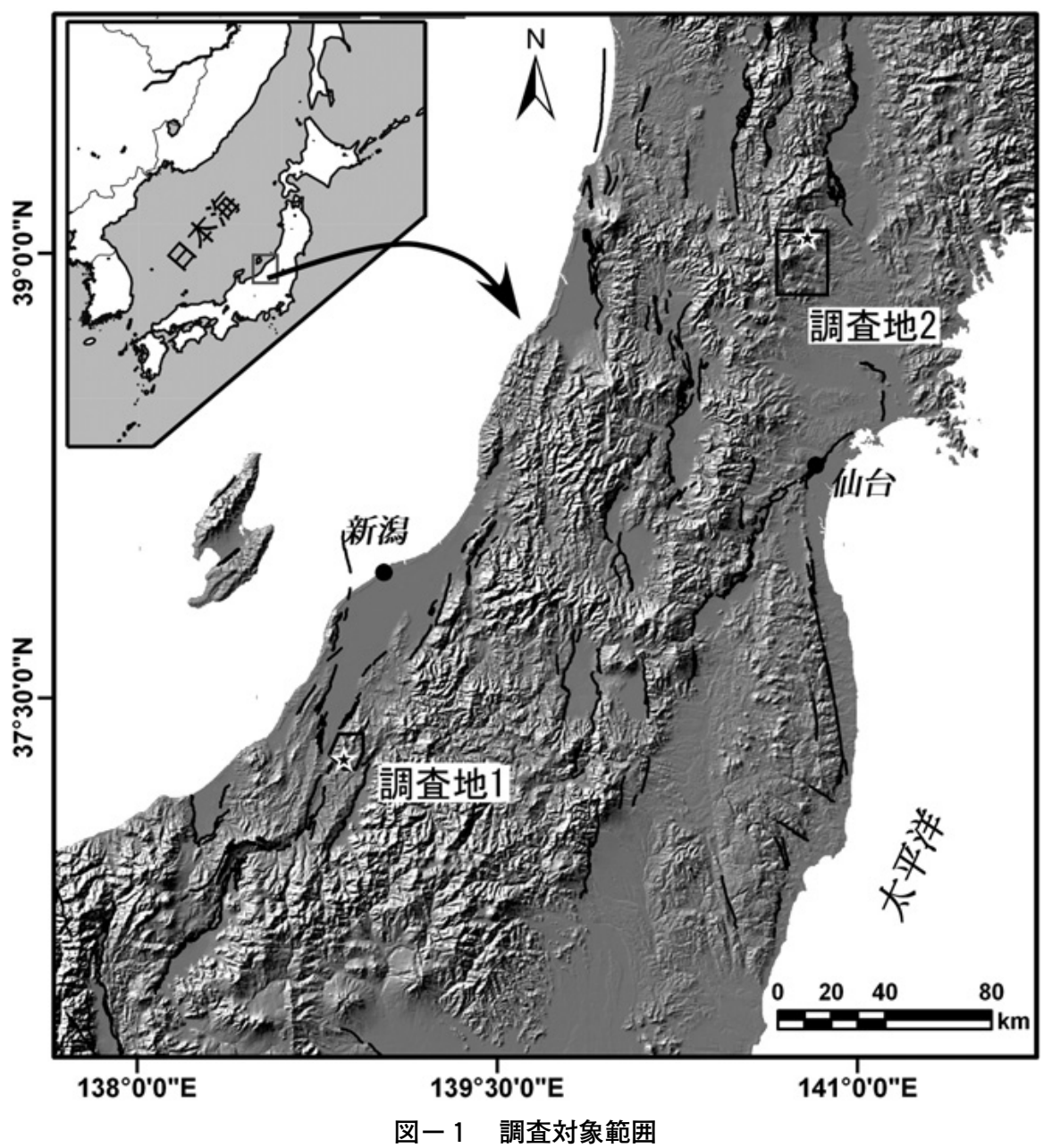

実線は活断層（産業技術総合研究所, 2009）を, 星印は調査地 1 では中越地震の震央, 調查地 2 では岩手・宮城内陸地震の震 央を示す。

Fig. 1 Location of the study areas

Solid lines indicate active faults based on AIST (2009). The star marks indicate epicenters of the Chuetsu earthquake in study area 1 and Iwate-Miyagi inland earthquake in study area 2. 


\section{3. データソースと地すべり発生要因}

調査地 1,2 において，既存地すべり地形と地震による 地すべりのデータセットを作成した。地すべりの判読は, 地震発生前後の空中写真判読及び，一部現地調査によっ て実施した。判読に用いた空中写真や解析に使用した DEMのデータソースを表ー 1 に示した。なお，調查地 2 における既存地すべり地形は，国土地理院（2009）の 判読結果を使用した。ここでは，地震による地すべりと は地すべり移動体が発生域に一部残留しているものであ り，明らかに表層崩壊や土石流等により移動したと判断 されるものは含まれない。また，ここでは既存地すべり 地形は，滑落崖を含まない土砂移動体の範囲を指す。

図 - 2 には, 調査地 1 と調査地 2 の既存地すべり地形 と地震による地すべりの分布を示した。調査地 1 （図一 2 の)では，既存地すべり地形が1, 050箇所判読され(ハ スバートルほか，2009)，この内，87箇所が中越地震時
に滑動した。調査地 2（図-2のb）には, 既存地すべ り地形が973箇所判読され, その内29箇所が岩手 · 宮城 内陸地震により滑動した。

本研究では，地震による地すべりの発生要因として地 形デー夕に注目し，既存地すべり地形内の凹凸度を示す 標高偏差，地すべり地形周辺の侵食状況を示す縁辺侵食 率と稜線や河川から地すべり地形までの距離を用いた。 この他に，地すべり地形の斜面勾配，下端勾配(ハスバー トルほか，2009），曲率なども，危険度評価の有効な指 標として考えられる。しかし，斜面勾配の取得には地す べり地形の測線設定や下端勾配の場合は遷急点を同定す るなど，経験と労力が必要である。曲率はGISソフトの 機能を用いて計算できるが，セル単位の凹凸を表現でき るものの地すべり地形全体の凹凸を表現するものではな い。これらのことを考慮し，本研究では，取得が容易な 地形デー夕を用いることとし，斜面勾配，下端勾配や曲

表ー 1 データソースー覧表

Table 1 A list of data sources

\begin{tabular}{|c|c|c|c|c|c|}
\hline 地震 & データ & \multicolumn{2}{|c|}{ 縮尺・解像度 } & 撮影・作成年 & 撮影・作成機関 \\
\hline \multirow{4}{*}{ 中越地震 } & \multirow{3}{*}{ 空中写真 } & \multirow{2}{*}{ 地震前 } & $1: 10,000$ & 1975年11月, 1976年11月 & 国土地理院 \\
\hline & & & $1: 25,000$ & 1999年6月 & 国土地理院 \\
\hline & & 地震後 & $1: 10,000 \sim 12,000$ & 2004年10月 24～29日 & 国土地理院 \\
\hline & DEM & 地震前 & $10 \mathrm{~m}$ & 1993年 & 北海道地図（株） \\
\hline \multirow{4}{*}{$\begin{array}{c}\text { 岩手 ·宮城 } \\
\text { 内陸地震 }\end{array}$} & \multirow{3}{*}{ 空中写真 } & 地震前 & $1: 30,000$ & 2006年10月 & 国土地理院 \\
\hline & & \multirow{2}{*}{ 地震後 } & $1: 10,000$ & 2008年6月 16,18 日 & 国土地理院 \\
\hline & & & $1: 10,000$ & 2008年6月 16, 18日 & アジア航測（株） \\
\hline & DEM & 地震前 & $10 \mathrm{~m}$ & 1993年 & 北海道地図（株） \\
\hline
\end{tabular}
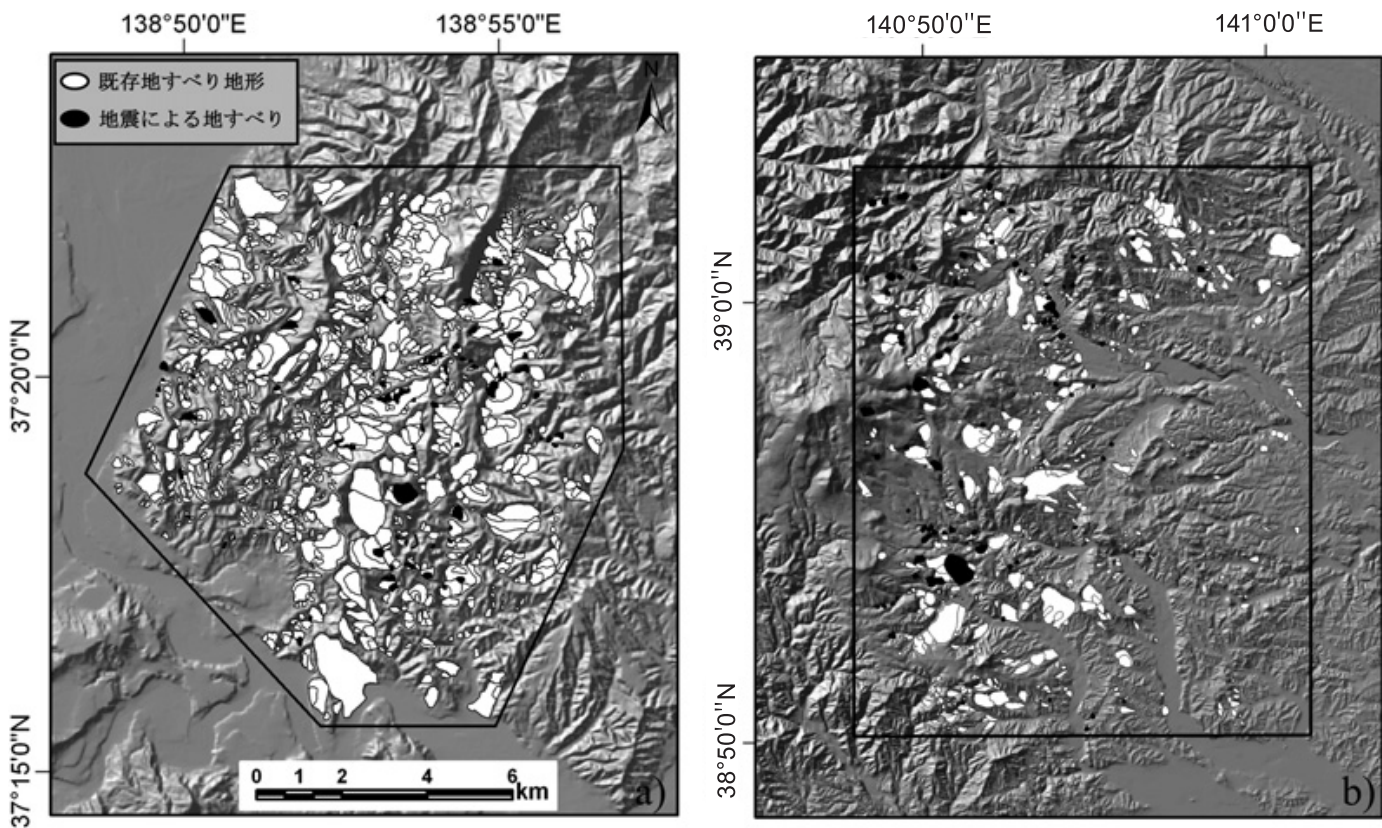

図ー2＼cjkstart調査地の地すべり分布図

a）中越地震；b）岩手・宮城内陸地震（既存地すべり地形は国土地理院，2009による）。

Fig. 2 Landslide distribution map of study areas

a) Chuetsu earthquake; b) Iwate-Miyagi inland earthquake (pre-existing landslide topographies are from GSI, 2009). 
率などは考慮しなかった。また，これら以外に地質要因 も考えられるが，地域性があるため用いなかった。

分析に用いたデータは次の通りである。なお，下記の 項目 (2)〜 (4) は既存の数值標高モデル（DEM）を基に ArcGISを用いて算出したもので，項目 (5) は筆者らが判 読して取得したデータである。

(1) 数值標高モデル (DEM) : 数值標高モデルは地形の 空間分布を表現できることから，地すべり発生に寄与す る標高偏差，河川や稜線データの作成に用いた。本論文 で使用したDEMは，北海道地図 (株)による地震発生前

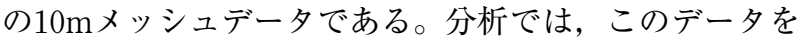
$30 \mathrm{~m}$ ッシュのラスターデータにして使用した。図－3 aに調査地 1 の標高値を示した。

(2) 河川から地すべりまでの距離：これは上述のDEMを 用いて河川ベクターを作成し（図－3b），ArcGISの機 能を用いて河川線から既存地すべり地形の重心までの距 離を求めたものである。河川ベクターは，上流域内に入 るセル数を 300 として計算した。地すべり斜面が河川か ら近いほどその末端部が侵食を受けると考え，河川から 地すべり地形までの距離を地すべり発生の要因とした。

(3)稜線から地すべりまでの距離：これは上記のDEMか ら稜線ベクターデータを作成し（図－ $3 \mathrm{~b}$ )，稜線から 既存地すべり地形の重心までの最短距離を求めたもので ある。稜線ベクターは，DEMの值をマイナスにし，河
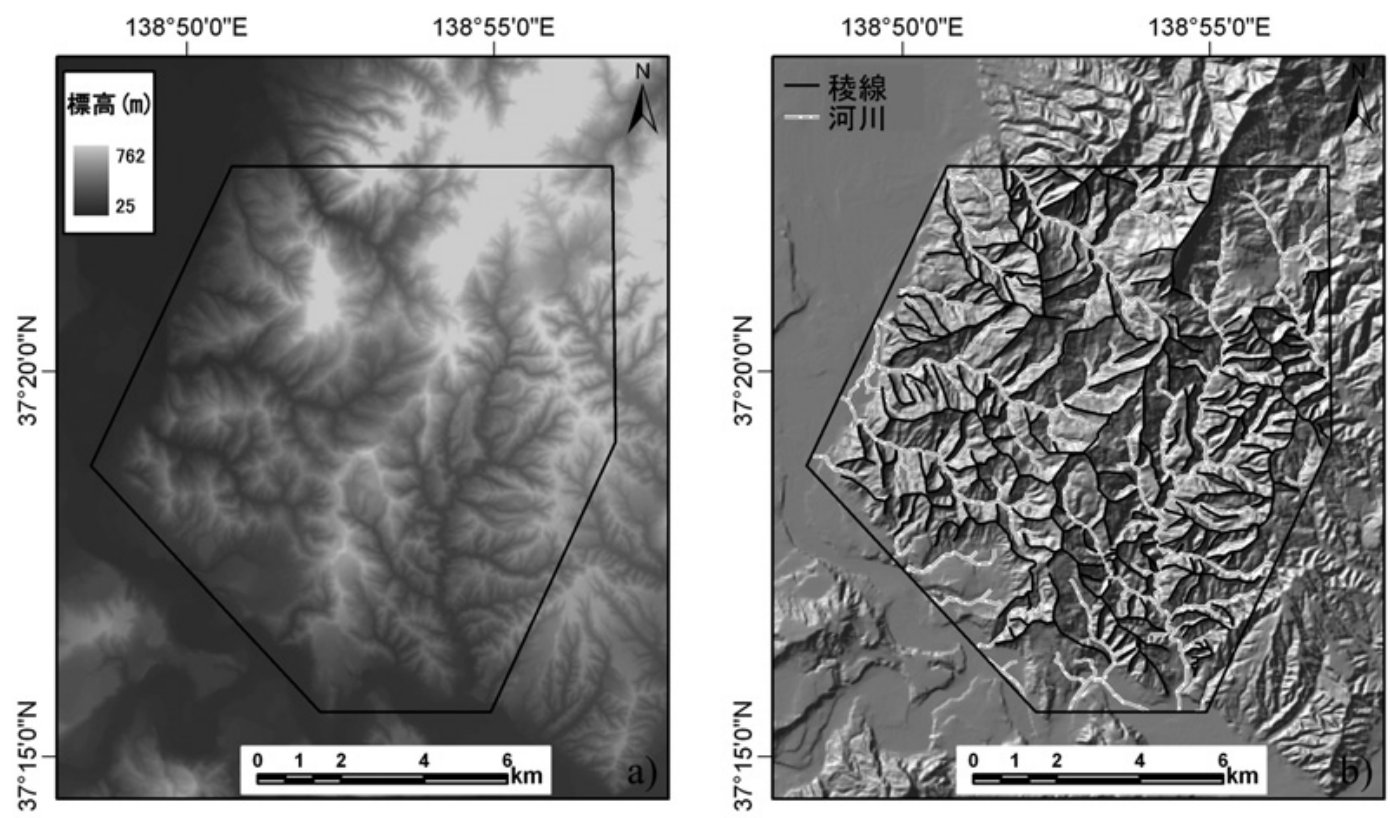

$138^{\circ} 55^{\prime} 0^{\prime \prime} \mathrm{E}$

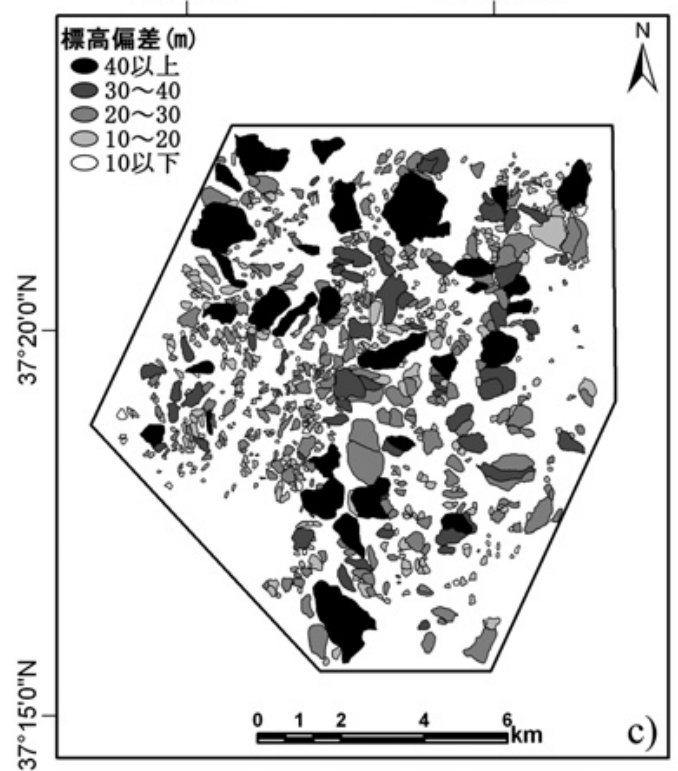

$138^{\circ} 50^{\prime} 0^{\prime \prime} \mathrm{E}$

$138^{\circ} 55^{\prime} 0^{\prime \prime} \mathrm{E}$

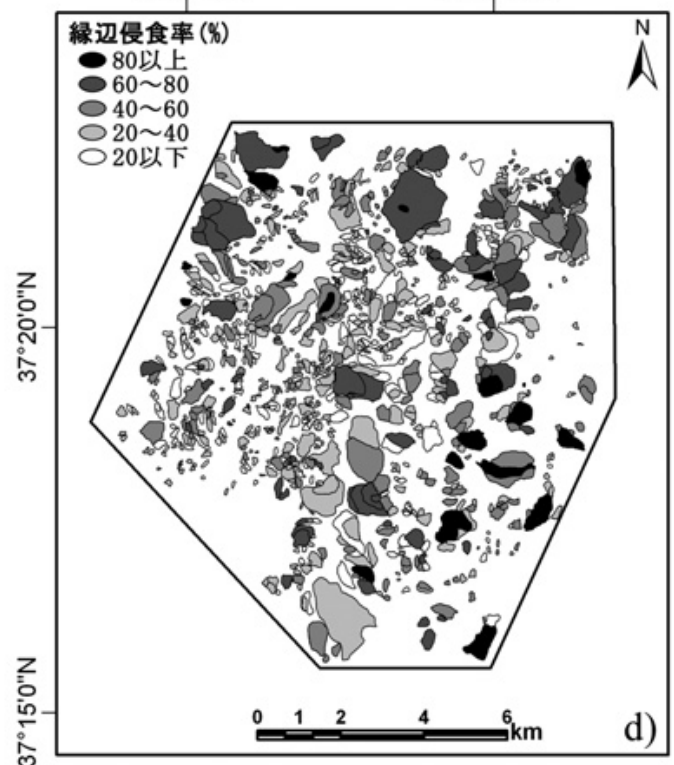

図－3 調査地 1 の標高 (a)，稜線と河川（b)，標高偏差（c）及び縁辺侵食率（d）分布図。

Fig. 3 Elevation (a), ridge and channel lines (b), surface roughness (c) and marginal erosion ratio map (d) of the study area1. 
川ベクターと同じ方法で算出した。地震では，稜線に近 いほど摇れが大きいとされる (Meunier et al., 2008) こ とから，稜線からの距離を地すべり発生の要因と考えた。 (4) 標高偏差 : 標高偏差は, 既存地すべり 地形内に含ま れる標高メッシュの地表面標高の標準偏差值である。図 - 4 にその概念を示した。標高偏差は, 斜面勾配と地す べり地形の面積に関係し，標高偏差が大きくなるほど勾 配が急になるか，または面積が大きくなることを表す。 このことにより，勾配が急になるほど地震により斜面安 全率の低下が起こる確率が高くなることや，面積が大き くなるほど地すべり斜面の一部が移動する確率が高くな ることが考えられる。この指標は，DEMデー夕により ArcGISの機能を用いて容易に算出できる。

(5) 縁辺侵食率：地すべり地形の周辺長 $(L)$ に対する 侵食地形長の割合である（Suzuki et al., 2010）。図5 に縁辺侵食率の算出方法を示した。侵食地形長 $(l)$ は, 地すべり斜面末端が河川や谷に面する部分の長さと, 側 部が侵食谷などの谷地形を呈する谷線の長さを合計した ものである。この谷線の長さは，土石流危険溪流抽出の 際の 1 次谷の判定基準（建設省河川局砂防部砂防課, 1999）と同様に，開口幅より奥行きの方が大きくなって いる範囲とした。また，既存地すべり地形の周辺長は地 すべり地形ポリゴンデータからA ArcGIS上で自動計算し て取得し，侵食地形長は判読者の地形図や空中写真判読 結果をArcGIS上にポリゴン化して，その長さを自動計 算した。既存地すべり地形では，侵食地形長が長いほど, 地すべり地形周辺の侵食が進み，地すべり斜面が不安定 な状態にあると考えられる。この指標に用いる地すべり 地形の侵食長は，地形図や空中写真判読で容易に抽出で きる。これらのことを考虑し, 縁辺侵食率を地すべり発 生の要因としてモデル構築に用いた。

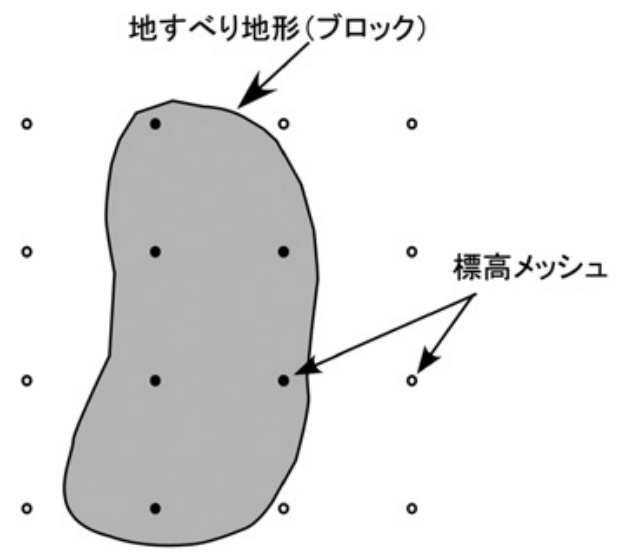

図一４標高偏差の概念図

標高偏差は，地すべりブロック内に含まれる標高メッシュ （黒丸）の標高值の標準偏差值である。

Fig. 4 Image of surface relief.

It is calculated as the standard deviation of elevation mesh (solid dots) inside the pre-existing landslide topography.

\section{4.ロジスティック回帰分析}

ロジスティック回帰分析は, 目的変数がカテゴリー データで，説明変数が数量データ，カテゴリーデータお よびその混合の時に用いられる多変量解析手法である。

この手法は，地震による地すべりのような発生・非発生 に分けられる自然現象の発生予測に適している。

あるイベント（ここでは地震による地すべりの発生） の発生確率を $P$ とすると, 発生確率 $P$ は次のように表せる。

$$
P=1 /\left(1+\mathrm{e}^{-Y}\right)
$$

ここで， $Y$ はロジットと呼ばれ，オッズ $P /(1-P)$ の 自然対数であり，次の式で表せる。

$$
Y=\log [P /(1-P)]=B_{0}+B_{1} X_{1}+B_{2} X_{2}+\cdots+B_{n} X_{n}
$$

ここで， $X_{1} ， X_{2}, \cdots, X_{n}$ は地すべりの発生に影響す る説明変数である。 $B_{0}$ はロジスティック回帰モデルの 定数， $B_{1} ， B_{2}, \cdots, B_{n}$ 偏回帰係数であり, $Y$ の值は, $-\infty$ からのに変化し，これらの説明変数と線形関係にな る。発生確率 $P$ は, 地すべり発生の予測において $0 \sim 1$ で示される。説明变数の係数 $B$ は, 最尤法によって推定 される。係数 $B_{n}$ の有意性は, Wald検定により 0.01 以下 の場合であれば0.01レベルで有意であることを示す。

\section{5. ロジスティック回帰モデルの構築と検証}

\section{1 モデルの構築}

ロジスティック回帰分析には，SPSS（IBM）の統計 処理ソフトSPSS Statistics V.19を用いた。分析ではス テップワイズ法（forward Wald）を用いて，調查地 1 で得られたデー夕を元に説明変数を選定し，その偏回帰 係数を求めた。目的変数は，既存地すべり地形における 地震による地すべりの発生・非発生である。説明変数

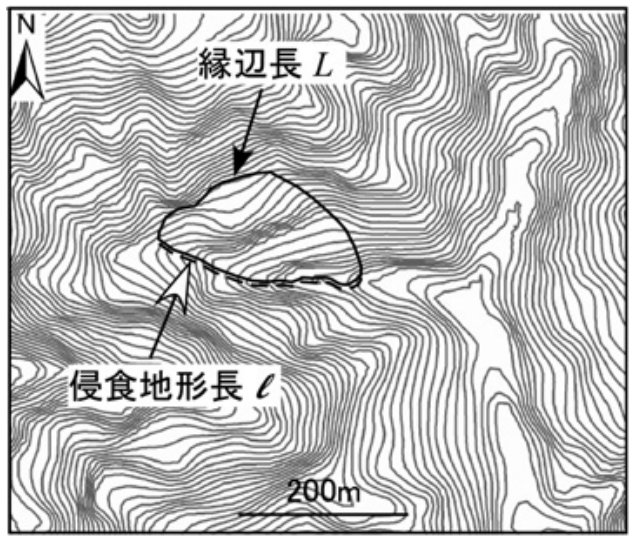

図一 5 縁辺侵食率の計算方法

地すべり地形の周辺長に占める侵食地形長の割合 $(l / L *$ 100)

Fig. 5 Calculating method of marginal erosion ratio.

It is calculated as the erode valley length divided by the marginal length of pre-existing landslide topography. 
は, 3章に述べた河川及び稜線からの距離，標高偏差，地 すべり地形縁辺侵食率の各項目である。

ロジスティック回帰分析では，地すべり発生・非発生 のデータ数が異なる場合，同数のサンプルで解析する例 が多い（Dai and Lee, 2002 ; Suzen and Doyuran, 2004 ; Chang et al., 2007 ; Mathew et al., 2009 ; Chauhan et al., 2010)。本研究でも, 調査地 1 の地すべ り発生箇所数が全既存地すべり地形数の約 $8.0 \%$ (87/ 1050×100）であり，地すべり発生数が地すべり非発生 数よりはるかに少ない。このため，分析では地すべり発 生・非発生のデー夕数を同数にして行った。ここで，分 析に用いられたデータとして, 調査地 1 における地震で 地すべりが発生した既存地すべり地形87箇所と，地すべ り非発生の963箇所からランダムに選んだ87箇所を合わ せた174箇所のサブデータセットを用意した。また，ロ ジスティック回帰モデルの有効性を検証するため，この サブデータセット（発生87, 非発生87）の中からランダ ムに約75\%である130箇所（発生65, 非発生65）を抽出し, それをモデル構築に用いた。残りの約 $25 \%$ のデータであ る44箇所（発生22, 非発生22）は，モデルの検証に用いた。 地すべり発生要因の各項目を用いて，ロジスティック 回帰分析を行った。ここでは, 変数選択にステップワイ ズ法の変数増加法を用いて，自動的に有意な変数を選択 した。この方法では, 有意確率 $P$ 值が最も小さいものか らモデルに投入し，尤度比検定量の減少が有意であれば 次にP值が小さいものを投入していく。尤度比検定量の 変化が有意ではなかったり，残った変数の $P$ 值が一定以 上になると終了する。分析の結果，標高偏差と縁辺侵食 率が，既存地すべり地形の地震時における地すべり発生 に影響していることが示され，モデルに残った。これら 以外の項目は，モデルから排除された。モデルに残った 項目とその係数を，表一 2 に示した。得られたモデルを
式(3)に示す。

$$
P=1 /[1+\exp \{-(0.060 S R+0.035 M E R-2.630)\}]
$$

ここで，SRは標高偏差，MERは縁辺侵食率である。 式(3)による地すべり発生予測の的中率を表 -3 に示 した。ここで，地すべりの発生予測確率は， $P>0.50$ を 地すべり発生， $P \leqq 0.50$ を地すべり非発生としている。 地すべり発生に対する的中率は70.8\%,地すべり非発生に 対する的中率は $78.5 \%$ ，全体の的中率は $74.6 \%$ であった。

\section{2 ロジスティック回帰モデルの検証}

\subsection{1 検証 1}

式(3)の有効性を検証するため，モデル構築に使用し なかった残りのデー夕（発生22，非発生22）を用いて， 地すべりの発生予測を行った。予測の結果を表一 4 に示 す。予測の的中率は，地すべり発生は $77.3 \%$ ，非発生は $72.7 \%$ ，全体は $75.0 \%$ あり，式(3)の妥当性が検証さ れた。

予測モデルの検証にはROC曲線が用いられることが 多い (Zweig and Campbell, 1993 ; Mathew et al., 2009)。ROCは, Receiver Operating Characteristicの 略称で，第 2 次大戦のときに米国のレーダーの研究から 生まれた概念である。受信者操作特性あるいは受信者動 作特性などと訳されることがあるが，ここではROC曲 線とする。

ロジスティック回帰分析のように，2值の分類予測を 行った場合，その観察に対し予測結果を表－5のように 示すことができる。地すべり発生の的中率が感度と呼ば れ，全地すべり発生数に占める的中した地すべり発生数 の割合で表される。また，地すべり非発生の的中率は特 異度と呼ばれ，全地すべり非発生数に占める的中した地 すべり非発生数の割合である。 ROC曲線は，各分離值

表一 2 ロジスティック回帰モデルに用いられた説明変数とその係数

Table 2 The predictors remained in the final logistic regression model and their coefficients

\begin{tabular}{l|c|c|c|c|c|c}
\hline \multicolumn{1}{c|}{ 説明変数 } & $B$ & $S E$ & Wald & $d f$ & Sig. & $\operatorname{Exp}(B)$ \\
\hline 標高偏差 & 0.060 & 0.019 & 9.631 & 1 & 0.002 & 1.061 \\
\hline 縁辺侵食率 & 0.035 & 0.010 & 13.336 & 1 & 0.000 & 1.036 \\
\hline 定数 & -2.630 & 0.579 & 20.607 & 1 & 0.000 & 0.072 \\
\hline
\end{tabular}

$B$ : 係数 $; S E$ : 標準詰差 $;$ Wald : カイ2乗 $; d f$ : 自由度 $; S i g$. : 有意確率 $; \operatorname{Exp}(B): B$ の指数

\section{表一 3 ロジスティック回帰モデルの的中率}

Table 3 Classification summary of the logistic regression model

\begin{tabular}{|c|c|c|c|c|}
\hline & & \multicolumn{2}{|c|}{ 予測 } & \multirow{2}{*}{ 的中率 $(\%)$} \\
\hline & & 地すべり発生 & 地す心゙り非発生 & \\
\hline \multirow{2}{*}{ 観測 } & 地すべり発生 & 51 & 14 & 78.5 \\
\hline & 地す心゙り非発生 & 19 & 46 & 70.8 \\
\hline \multicolumn{4}{|l|}{ 全体 } & 74.6 \\
\hline
\end{tabular}

分類值は 0.50
表一 4 検証 1 中越地震の的中率

Table 4 Classification summary of validation 1 for the Chuetsu earthquake

\begin{tabular}{l|c|c|c|c}
\hline \multirow{2}{*}{} & \multicolumn{2}{|c|}{ 予測 } & \multirow{2}{*}{ 的中率 (\%) } \\
\cline { 3 - 4 } \multicolumn{2}{c|}{} & 地すべり発生 & 地すべり非発生 & \\
\hline \multirow{2}{*}{ 観測 } & 地すべり発生 & 17 & 5 & 77.3 \\
\cline { 2 - 4 } & 地すべり非発生 & 6 & 16 & 72.7 \\
\hline \multicolumn{2}{|l|}{ 全体 }
\end{tabular}

分類値は 0.50 
(ここではロジスティック回帰モデルにより計算した確 率值）の高い順から横軸に 1 - 特異度（空振り率：全地 すべり非発生数に占める地すべり発生予測のはずれ数の 割合）を，縦軸に感度をプロットして作成したものであ る。ROC曲線の下部面積が大きいほどモデルの精度が 良く，一般的に0.9-1.0が「優」，0.8-0.9が「良」で, 0.7 -0.8が「可」とされる (Craig et al. , 2007)。上述44の 地すべり地形を対象に，ROC曲線を図ー 6 に示した。 曲線の下部の面積（AUC：Area under the curve）が 精度を表す。AUCが0.804で，予測精度が「良」である ことを示す。

\subsection{2 補正と検証 2}

上述の式 (3) 作成時のデータによる地すべり発生率と 全デー夕による地すべり発生率が異なることから，ロジ スティック回帰式の定数の補正（高田，2007）を行った。 補正は(4)，(5) 式により行い，(6)式を得た。

$$
q_{1} / q_{2}=\{s(1-r)\} /\{r(1-s)\}
$$

ここで，rは全データによる地すべり発生率（87/1050 $\doteqdot 0.08)$

$s$ は式 $(3)$ 作成時データの地すべり発生率 $(65 / 130=$ $0.50)$

$$
\begin{gathered}
P_{m}=1 /\left[1+\exp \left\{-\left(-\log \left(q_{1} / q_{2}\right)+0.060 S R+\right.\right.\right. \\
0.035 M E R-2.630)\}] \cdots(5) \\
P_{m}=1 /[1+\exp \{-(0.060 S R+0.035 M E R-5.032)\}]
\end{gathered}
$$

式 (5) は, 定数補正後のロジスティック回帰モデルで ある。

この補正したモデルを用いて，調査地 2 の地すべり発 生予測を行い，その有効性を検証した。予測の的中率を 表 -6 に示す。的中率は，地すべり発生 $75.9 \%$ ，非発生 及び全体は $75.0 \%$ であた。なお，ここでは，地すべり の発生・非発生は，(2)式を求めた中越地震における地 すべり発生率 0.08 をとに, $P_{m}>0.08$ を発生, $P_{m} \leqq 0.08$
を非発生としている。岩手・宮城内陸地震のデー夕を用 いたROC曲線を図 - 6 に示す。曲線の下部の面積AUC が0.835であり，式(6)の予測能は「良」であることが示 された。これにより，補正後のロジスティック回帰モデ ルの有効性が確認された。

\section{3 既存地すべり地形の危険度評価}

上述補正後のロジスティック回帰モデルの有効性が確 認されたことから，それを用いて中越地震と岩手・宮城 内陸地震の調查地のデータを用いて，既存地すべり地形 の地震時における地すべり発生危険度評価について検討 した。

中越地震による全データを用いて，ロジスティック回 帰モデル（式 5 ）により，各地すべり地形の地震による 地すべり発生確率 $P_{m}$ を求めた。図 -7 には，地すべり の発生，非発生の相対度数及び地すべり発生率を示した。 地すべり発生率は， $P_{m}$ の上昇に伴い増大しており， $P_{m}$ が0.40以上では更に増大している。そこで，地震による 地すべり発生の危険度を， $P_{m} \leqq 0.08$ 危険度低， 0.08 $<P_{m} \leqq 0.4$ を危険度中, $P_{m}>0.4$ を危険度高としてラン

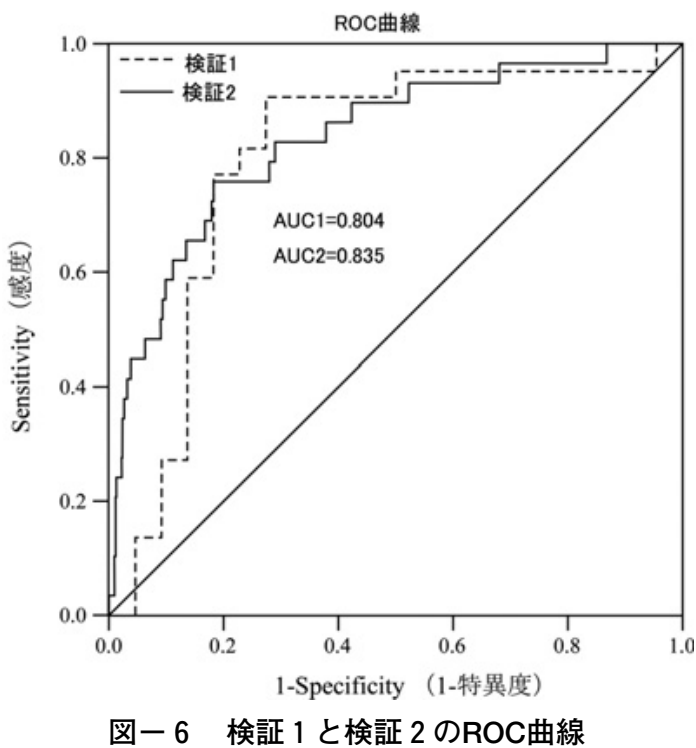

\begin{tabular}{|c|c|c|c|}
\hline & \multicolumn{2}{|c|}{ 予測 } \\
\hline & & $\begin{array}{c}\text { Positive } \\
\text { 地すべり発生と予測 } \\
\end{array}$ & $\begin{array}{c}\text { Negative } \\
\text { 地すべり非発生と予測 }\end{array}$ \\
\hline \multirow{2}{*}{$\begin{array}{l}\text { 観 } \\
\text { 測 }\end{array}$} & $\begin{array}{c}\text { True } \\
\text { 地すべり発生 }\end{array}$ & $\begin{array}{l}\text { true positive(TP) } \\
\text { 地すべり発生の的中数 }\end{array}$ & $\begin{array}{l}\text { false negative(FN) } \\
\text { 地すべり非発生のはずれ数 }\end{array}$ \\
\hline & $\begin{array}{c}\text { False } \\
\text { 地すべり非発生 }\end{array}$ & $\begin{array}{l}\text { false positive }(\mathrm{FP}) \\
\text { 地すべり発生のはずれ数 }\end{array}$ & $\begin{array}{l}\text { true negative }(\mathrm{TN}) \\
\text { 地すべり非発生の的中数 }\end{array}$ \\
\hline & $\begin{array}{l}\text { Sensitivity } \\
\text { 感度 }\end{array}$ & \multicolumn{2}{|c|}{$\begin{array}{c}\mathrm{TP} /(\mathrm{TP}+\mathrm{FN}) \\
\text { 地すべり発生的中数/全地すべり発生数 }\end{array}$} \\
\hline & $\begin{array}{l}\text { Specificity } \\
\text { 特異度 }\end{array}$ & \multicolumn{2}{|c|}{$\begin{array}{c}\mathrm{TN} /(\mathrm{TN}+\mathrm{FP}) \\
\text { 地すべり非発生の的中数/全地すべり非発生数 }\end{array}$} \\
\hline
\end{tabular}

Fig. 6 ROC curves of validation 1 and validation2.

表一 5 予測結果, 感度及び特異度

Table 5 Outcomes, sensitivity and specificity of prediction 
ク分けした。

調査地1，2における危険度評価の結果を図－8に示し た。また，危険度評価ランクと地すべりの数，面積など を表 -7 に示した。調査地 1 においては, 危険度高の地 すべりは全体の $3.6 \%$ 占め，危険度中は $27.6 \%$ あっ た。しかし，面積の割合では危険度高は $20.9 \%$ ，危険度

表-6 検証 2 岩手・宮城内陸地震の的中率

Table 6 Classification summary of validation 2 for the Iwate-Miyagi inland earthquake

\begin{tabular}{|c|c|c|c|c|}
\hline & & \multicolumn{2}{|c|}{ 予測 } & \multirow{2}{*}{ 的中率 $(\%)$} \\
\hline & & 地す心゙り 発生 & 地すべり非発生 & \\
\hline \multirow{2}{*}{ 観測 } & 地すべり発生 & 22 & 7 & 75.9 \\
\hline & 地すべり非発生 & 236 & 708 & 75.0 \\
\hline \multicolumn{4}{|l|}{ 全体 } & 75.0 \\
\hline
\end{tabular}

分類値は 0.08

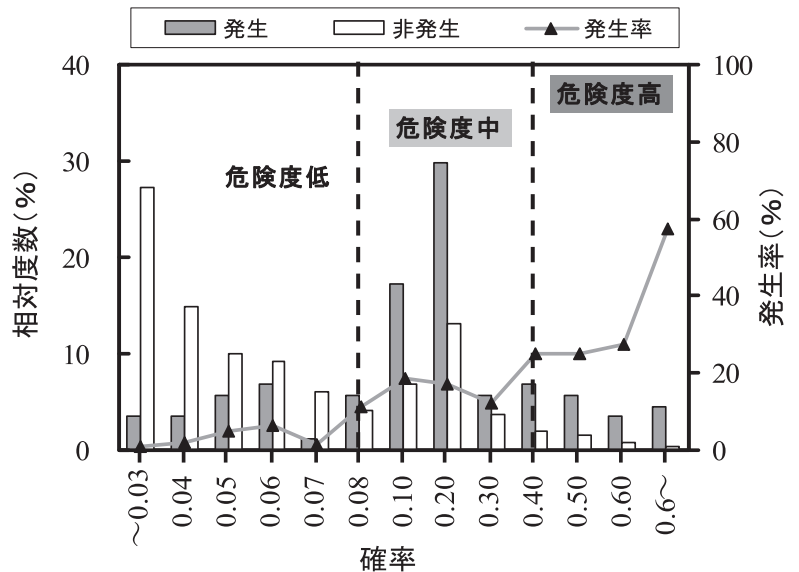

図ー 7 中越地震による地すべりの危険度評ランク

Fig. 7 Susceptibility rank of landslides induced by the Chuetsu earthquake

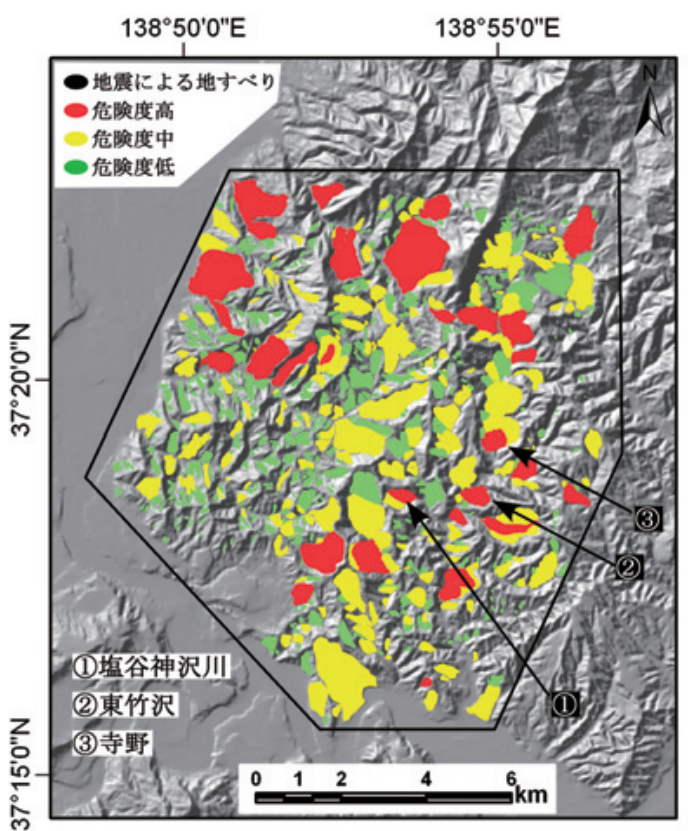

調查地 1
中は $47.0 \% て ゙ あ り ，$ 危険度が高いほど地すべりの規模が 大きい傾向を示した。この傾向は，岩手・宮城内陸地震 の場合も同様であった。

なお，中越地震では，塩谷神沢川地すべり（図－8の (1)），東竹沢地すべり（図-8の(2)）や寺野（図-8の (3)）などの地すべりは危険度高と予測された。

\section{6. 考察}

本論文では，地震による地すべりの発生危険度をグ リッド単位で評価するこれまでの研究と異なり，既存地 すべり地形を対象とし，地すべりブロック単位で評価し た。地すべり対策は，地すべりブロックを対象として行 われる。また，既存地すべり地形は比較的容易に判読で き，ロジスティック回帰モデルに用いた標高偏差と縁辺 侵食率のデー夕の取得もそれほど困難ではない。これら のことから，地すべり対策を考慮した場合，本研究で提 案した手法は有効性が高いといえる。

一方，本論文の方法は，既存地すべり地形を対象とし ているため，初生地すべりについては適用できない。中 越地震による地すべりの一部のデータを用いて構築した ロジスティック回帰モデルを検証・補正した上で岩手 · 宮城内陸地震による地すべりの発生を予測した結果，的 中率が $75 \%$ とモデルの有効性が確認された。この結果か ら，モデルに用いられた標高偏差と縁辺侵食率は地すべ り発生に影響する有効な要因であることが示唆された。 セルを単位とした地震による地すべりの発生危険度評価 には，標高（例えばKamp et al. ，2008）や標高差（例 えばPareek et al., 2010）が用いられている。今回は, 既存地すべり地形内の起伏を定量的に表現するため標高 偏差を用いた。標準偏差はデータのばらつきを表す指標

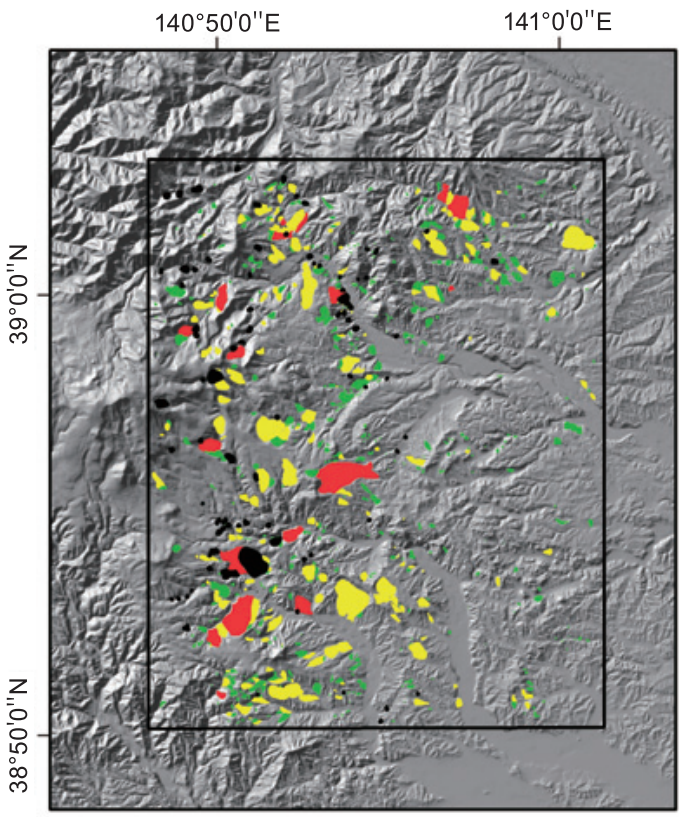

調査地 2

図-8 調查地の危険度評価図

Fig. 8 Susceptibility map of the study areas 
表一 7 調査地の地震による地すべりの危険度評価結果

Table 7 Susceptibility of landslide of the two study areas

\begin{tabular}{c|l|c|c|c|c}
\hline 地震 & \multicolumn{1}{|c|}{ 危険度 } & 危険度高 & 危険度中 & 危険度低 & 合計 \\
\hline \multirow{4}{*}{\begin{tabular}{c} 
調 \\
查 \\
地 \\
\cline { 2 - 6 }
\end{tabular}} & 箇所数 & 38 & 290 & 722 & 1050 \\
\cline { 2 - 6 } & 全箇所に占める割合 \% & $\mathbf{3 . 6}$ & $\mathbf{2 7 . 6}$ & $\mathbf{6 8 . 8}$ & 100 \\
\cline { 2 - 6 } & 平均面積 ha & 1237.8 & 2782.5 & 1899.1 & 5919.4 \\
\cline { 2 - 6 } & 全面積に占める割合 \% & $\mathbf{2 0 . 9}$ & $\mathbf{4 7 . 0}$ & $\mathbf{3 2 . 1}$ & 100 \\
\hline \multirow{4}{*}{$\begin{array}{c}\text { 調 } \\
\text { 查 } \\
\text { 地 } \\
2\end{array}$} & 箇所数 & 21 & 236 & 716 & 973 \\
\cline { 2 - 6 } & 全箇所に占める割合 \% & $\mathbf{2 . 2}$ & $\mathbf{2 4 . 3}$ & $\mathbf{7 3 . 6}$ & 100 \\
\cline { 2 - 6 } & 総面積 ha & 942.7 & 2798.9 & 1625.0 & 5366.6 \\
\cline { 2 - 6 } & 平均面積 ha & 44.9 & 11.9 & 2.3 & 59.0 \\
\cline { 2 - 6 } & 全面積に占める割合 \% & $\mathbf{1 7 . 6}$ & $\mathbf{5 2 . 2}$ & $\mathbf{3 0 . 3}$ & 100 \\
\hline
\end{tabular}

であるため，既存地すべり地形内の標高のばらつきの指 標となり，結果的に地形の凹凸の程度を示すものと考え られる。縁辺侵食率は，地すべり地形の周辺の侵食の程 度を定量的に表すために考えられた指標（Suzuki et al., 2010）であり，今回はその有効性が確認された。既存地 すべり地形縁辺の侵食が進むことにより，地すべり移動 体がより不安定な状態を示していると推定される。一方, 河川と稜線から地すべりまでの距離データは，モデルに 採用されなかった。その理由として，稜線からの距離が 近いほど地震の摇れが大きいことが期待されるものの, 調査地では，距離デー夕に有意な差がなかったことによ る可能性がある。また，河川からの距離は，縁辺侵食率 の効果に含まれている可能性がある。

地形のみに注目した今回の危険度評価法は，筆者らの 先行研究の点数付け方法（ハスバートルほか, 2009）よ り定量的な評価手法になり，構築したモデルが検証され， モデルを構築した地域以外でも適用可能であることが示 された。本論文の結果は，マグニチュード 7 前後の逆断 層地震による地すべりデータから得られたものである。 今後は，筆者らの先行研究結果（ハスバートルほか, 2011）の逆断層地震による地すべりの多発範囲の設定と 合わせて，活断層（逆断層）周辺における既存地すべり 地形を対象にした地震時の地すべり発生危険度評価が期 待される。日本の主要な活断層は，長期評価されている （地震調查研究推進本部, 2011)。今後, 内陸型地震の予 測精度が向上し，活断層周辺の既存地すべり地形の地す べり発生危険度評価を行うことで，その結果が地すべり 対策の優先順位決定の一つの指標になると期待される。

本論文では，地形要因のみを用いて，既存地すべり地 形の地震による地すべり発生危険度評価を行った。しか し，地震時には既存地すべり地形以外で，初生地すべり も発生している。今後は，初生地すべりについて，地震 による地すべり発生危険度評価手法を検討していく予定 である。

\section{7. まとめ}

既存地すべり地形を対象に，ロジスティック回帰分析 を用いて地震時の地すべり発生危険度評価を行った。そ の結果，地形要因として標高偏差，縁辺侵食率が地すべ り発生に影響していることが明らかになった。また，中 越地震による地すべりデータをもとに作成したロジス ティック回帰モデルの検証を，中越地震による地すべり のデータの残りと岩手・宮城内陸地震のデータによりを 行った。その結果，地すべり発生予測の精度はROC解 析によればAUC (予測能) で 0.8 以上であり，モデルの 有効性が確認された。以上の結果，今後既存地すべり地 形の標高偏差と縁辺侵食率の地形デー夕を用いて，活断 層周辺の既存地すべり地形における地震時の地すべり発 生危険度評価が可能であることが示唆された。

\section{謝 辞}

匿名の査読者 2 名の方から建設的なコメントをいただ きました。記して，謝意を示す。

\section{参考文献}

Anbalagan, R.(1992) : Landslide susceptibility evaluation and zonation mapping in mountainous terrain, Engineering Geology, Vol. 32, Issue 4, pp. 269-277.

Ayalew, L. and Yamagishi, H.(2005) : The application of GISbased logistic regression for landslide susceptibility mapping in the Kakuda-Yahiko Mountains, Central Japan, Geomorphology, Vol. 65, Issues $1-2$, pp. $15-31$.

防災科学技術研究所 (2010)：地すべり地形分布図データベース, http://lsweb1. ess.bosai.go.jp/index.html(2010年10月28日参照).

Chang, K. T., Chiang, S. H. and Hsu, M. L.(2007) : Modeling typhoon-and earthquake-induced landslides in a mountainous watershed using logistic regression, Geomorphology, Vol. 89, Issues $3-4$, pp. $335-347$.

Chauhan, S., Sharma, M. and Arora, M. K. (2010) : Landslide susceptibility zonation of the Chamoli region, Garhwal Himalayas, using logistic regression model, Landslides, Vol. 7, No 4, pp. $411-423$

Chigira, M., Wu, X. Y., Inokuchi, T. and Wang, G. H.(2010) : Landslides induced by the 2008 Wenchuan earthquake, Sichuan, China, Geomorphology, Vol. 118, Issues $3-4$, pp. 225 
-235 .

Craig, L. A., Beech, A. R. and Brown, K. D. (2007) : Methodological considerations when estimating actuarial sexual recidivism risk, Forensic Update, 91 (Autumn 2007), pp. 32-39.

Dai, F. C. and Lee, C. F. (2002) : Landslide characteristics and slope instability modeling using GIS, Lantau Island, Hong Kong, Geomorphology, Vol. 42, Issues $3-4$, pp. 213-228.

Dong, J. J., Tung, Y. H., Chen, C. C., Liao, J. J. and Pan, Y. W. (2009) : Discriminant analysis of the geomophic characterisitcs and stability of landside dams, Geomorphology, Vol. 110 , Issues $3-4$, pp. $162-171$.

Garcia-Rodriguez, M. J., Malpica, J. A., Benito, B. and Diaz, M. (2008) : Susceptibility assessment of earthquake-triggered landslides in El Salvador using logistic regression, Geomorphology, Vol. 95, Issues 3 -4, pp. 172-191.

Guzzetti, F., Carrara, A., Cardinali, M. and Reichenbach, P. (1999) : Landslide hazard evolution: a review of current techniques and their application in a multi-scale study, Central Italy, Geomorphology, Vol. 31, Issues 1 -4, pp. 181-216.

ハスバートル・村中亮太・丸山清輝・花岡正明（2009）：新潟県中 越地震による地すべりの発生条件の検討, 日本地すべり学会 誌, Vol. 45, No.6, pp. 16-22.

ハスバートル・石井靖雄・ 丸山清輝 ・ 寺田秀樹 · 鈴木聡樹 · 中村 明 (2011) : 最近の逆断層地震により発生した地すべりの分 布と規模の特徵, 日本地すべり学会誌, Vol. 48, No. 1, pp. 23-38.

地震調查研究推進本部 (2011) : 活断層の長期評価, 地震調査研究 推進本部ホームページ :

http://www.jishin.go.jp/main/choukihyoka/katsu.htm（2011 年 3 月 22 日閲覧)

Kamp, U., Growley, B. J., Khattak, G. A. and Owen, L. A. (2008) : GIS-based landslide susceptibility mapping for the 2005 Kashmir earthquake region, Geomorphology, Vol. 101, Issue 4, pp. $631-642$.

建設省河川局砂防部砂防課（1999）：土石流危険渓流及び土石流危 険区域調査要領 (案), $17 \mathrm{p}$.

小林厳雄 ·立石雅昭・吉岡敏和・島津光夫（1991）：長岡地域の地 質，地域地質研究報告 ( 5 万分の 1 図幅)，地質調查所， $132 \mathrm{p}$

国土地理院（2009）：平成20年（2008年）岩手 - 宮城内陸地震 1 ： 25,000詳細活断層図（活断層・地形分類及び地形変状），国 土地理院技術資料D. 1 - No. 541 .

国土交通省砂防部（2005）：平成16年新潟県中越地震に伴う斜面崩 壊の発生状況について (続報), 国土交通省ホームページ： http://www.mlit.go.jp/kisha/kisha05/05/050113_html (2011 年 3 月 10 日閲覧)

国土交通省砂防部（2008）：平成20年岩手・宮城内陸地震河道閉塞 に対する調査と緊急対策の計画の概要, 砂防と治水, Vol. 41, No. 4 , pp. $23-24$.

Lee, C. T., Huang, C. C., Lee, J. F., Pan, K. L., Lin, M. L. and Dong, J. J. (2008) : Statistical approach to earthquake-induced landlside susceptibility, Engineering Geology, Vol. 100, Issues $1-2$, pp. $43-58$.

丸井英明 ·八木浩司 - 吉松弘行 - 千木良雅弘 - 阿部真郎 (2006)： パキスタン北部地震による地すべり災害に関する調査報告, 日本地すべり学会誌, Vol.43, No.2, pp.48-51.

Mathew J., Jha, V. K. and Rawat, G. S. (2009) : Landslide susceptibility zonation mapping and its validation in part of Garhwal Lesser Himalaya, India, using binary logistic regression analysis and receiver operating characteristics curve method, Landslides, Vol. 6, No. 1, pp. 17-26.

Meunier, P., Hovius, N. and Haines, J.(2008) : Topographic site effects and the location of earthquake induced landslides, Earth and Planetary Science Letters, doi : 10.1016/j. epsl. 2008. 07.020.

新潟県（2009）：平成16年新潟県中越大震災による被害状況につい て (最終報)，新潟県報道資料， $4 \mathrm{p}$.

大沢あつし・滝沢文教（1992）：日本地質図大系東北地方，朝倉書 店, $135 \mathrm{p}$.

Pack, R. T., Tarboton, D. G. and Goodwin, C. N.(1998) : The SINMAP approach to terrain stability mapping, $8^{\text {th }}$ congress of the international association of engineering geology, Vancouver, British Columbia, Canada, 21-25, September.

Pareek, N., Sharma, M. L. and Arora, M. K. (2010) : Impact of seismic factors on landslide susceptibility zonation: a case study in part of Indian Himalayas, Landslides, Vol. 7, No. 2, pp. $191-201$.

産業技術総合研究所（2009）：活断層データベース2009年 7 月 23 日 版. 産業技術総合研究所研究情報公開データベースDB095. http://riodb02.ibase.aist.go.jp/activefault/index.html（2011 年 3 月 10 日参照)

Soeters, R. and van Westen C. J.(1996) : Slope instability recognition analysis and zonation. In: Turner, K. T. and Schuster, R. L. (eds) Landslides: investigation and mitigation, Transportation Research Board National Research Council, Special Report, Washington, DC, pp. 129-177.

Suzen, M. L. and Doyuran, V.(2004) : A comparison of the GIS based landslide susceptibility assessment method: multivariate versus bivariate, Environmental Geology, Vol. 45, No. 5, pp. $665-679$

Suzuki, S., Has, B., Maruyama, K. and Ishii, Y.(2010),Risk evaluation of earthquake-induced landslide based on analysis of erosion condition on landslide marginal part, Chen Su-Chin ed. Interpraevent2010-Symposium proceedings, pp. 898-901.

高田直樹（2007）：ロジスティック回㷌分析結果の解釈・利用の ための新手法一信用リスク・スコアリングモデルを例に一， IBMプロフェッショナル論文 3 , pp. $71-77$, ProVISION No. 53 /spring 2007

牛山素行・太田好乃（2009）：平成20年（2008年）岩手・宮城内陸 地震による死者・行方不明者の特徵, 自然災害科学, Vol. 28, No. 1 , pp. $59-66$.

八木浩司・檜垣大助・日本地すべり学会平成14年度第三系分布域 の地すべり危険箇所調査手法に関する検討委員会（2009）： 空中写真判読とAHP法を用いた地すべり地形再滑動評価手 法の開発と阿賀野川中流域への適用, 日本地すべり学会誌, Vol. 45, No. 5, pp. $358-366$.

柳沢幸夫 - 小林厳雄 - 竹内圭史 - 立石雅昭 - 茅原一也 (1986)：小 千谷地域の地質，地域地質研究報告（5 万分の 1 図幅），地 質調査所, $177 \mathrm{p}$.

Yoshimatsu, H. and Abe, S. (2006) : A review of landslide hazards in Japan and assessment of their susceptibility using an analytical hierarchic process (AHP) method, Landslides, Vol. 3, No. 2, pp. 149-158. DOI : 10.1007/s10346-005$0031-\mathrm{y}$.

Zhou, G., Esaki, T., Mitani, Y., Xie, M. and Mori, J.(2003) : Spatial probabilistic modeling of slope failure using an integrated GIS Monte Carlo simulation approach, Engineering Geology, Vol. 68, Issues $3-4$, pp. $373-386$

Zweig, M. H. and Campbell, G. (1993) Receiver-operating characteristic (ROC) plots : a fundamental evaluation tool in clinical medicine, Clinical Chemistry, Vol. 39, No. 4, pp. 561-577.

（原稿受付2011年 3 月 31 日，原稿受理2011年10月17日） 